\title{
Comparative evaluation of hemodynamic stability and recovery during conscious sedation by dexmedetomidine with fentanyl versus ketamine with fentanyl in dilatation and curettage
}

\author{
Gehan Fouad kamel, Rania Magdy Ali, Ali Elsayed Ali Ismail, Beshoy Eshak Aziz Hanna* \\ Department of Anesthesia, Intensive Care and Pain Management, Faculty of Medicine, Ain Shams \\ University
}

*Corresponding author: Beshoy Eshak Aziz Hanna, Mobile: 01006940037; Email:

beshoyaziz310@gmail.com

\begin{abstract}
Background: Conscious sedation is a technique of providing analgesia, sedation and anxiolysis while ensuring rapid recovery without side effects. Conscious sedation is administered with the dual goals of rapidly and safely establishing satisfactory procedural condition for the performance of therapeutic or diagnostic procedures while ensuring rapid, predictable recovery with minimal post-operative sequels. Dexmedetomidine is a highly selective alpha-2 agonist that provides anxiolysis and cooperative sedation without respiratory depression. It inhibits the release of norepinephrine via actions on the alpha2A $(\alpha-2 \mathrm{~A})$ adrenoceptors located in the locus ceruleus and the spinal cord, resulting in sedation and analgesia via sympatholysis.
\end{abstract}

Objective: It was to study the effect of dexemdetomidine with fentanyl versus ketamine with fentanyl on hemodynamic stability and recovery during conscious sedation in dilatation and curettage procedure. The comparison included the vital data and recovery time. The effect of the drugs on hemodynamics and monitoring the occurrence of any complication were also done.

Patients and Methods: In our study, 50 patients were randomly divided into 2 equal groups; group DF received dexmedtomidine loading dose $1 \mu \mathrm{g} / \mathrm{kg}$ over $10 \mathrm{~min}$ and followed by $0.5 \mu \mathrm{g} / \mathrm{kg} / \mathrm{hr}$ infusion till completion of surgery and group $\mathrm{KF}$ received ketamine $0.5 \mathrm{mg} / \mathrm{kg}$ slow intravenous Bolus.

Results: Dexmedetomidine is a safe drug with good hemodynamic and recovery time, also exerts sedative and analgesic effects without respiratory depression, unlike most analgesic/sedative drugs, such as ketamine, opioids, benzodiazepines, and propofol.

Conclusion: This study demonstrates that dexmedetomidine is a safe drug with good hemodynamic and recovery profile. Dexmedetomidine better preserved MBP and $\mathrm{SpO} 2$.

Keywords: Dexmedetomidine, ketamine, fentanyl

\section{INTRODUCTION}

Conscious sedation is a technique of providing analgesia, sedation and anxiolysis while ensuring rapid recovery without side effects. Conscious sedation is administered with the dual goals of rapidly and safely establishing satisfactory procedural condition for the performance of therapeutic or diagnostic procedures while ensuring rapid, predictable recovery with minimal postoperative sequels ${ }^{(1)}$.

Dexmedetomidine is selective $\alpha 2$ adrenoceptor agonist that has sedative, sympatholytic, amnestic and analgesic effects; it has been placed in a number of clinical trials as useful and safe substance. Providing an excellent analgesia, conscious sedation in patients who seem to be asleep, however can easily be awaken, in addition no respiratory depression, make dexmedetomidine one of the widely used medication in anesthesia ${ }^{(2)}$.

These properties of dexmedetomidine render it suitable for sedation and analgesia during the whole perioperative period. Its applications as a premedication, as an anesthetic adjunct for general and regional anesthesia and as a postoperative sedative and analgesic are similar to those of the benzodiazepines ${ }^{(3)}$.

\section{AIM OF THE WORK}

The aim of this study is to investigate whether Dexmedetomidine with Fentanyl combination is an effective alternative modality to ketamine with fentanyl as sedation as regard hemodynamics stability and recovery 
for patients undergoing Dilatation and curettage procedure.

\section{Patients and Methods}

Study Settings: After obtaining approval from the Research Ethical Committee of Ain Shams University, this study was conducted in the operating theatres of Ainshams University Hospital.

Study Design: Double - blinded, randomized controlled trial.

Inclusion Criteria: Patients aged between $18-60$ years old, physical status: ASA I and II Patients, eight hours fasting.

Exclusion Criteria: Refusal of procedure or participation in the study, physical status: ASA III or above, renal insufficient, hepatic insufficient, cardiac disease or heart block, allergies to drugs used in the study.

Sample Size: 50 Patients divided to two groups, each group contained 25 patients: Group $(\mathbf{D}+\mathbf{F})$ : After Pre -operative vital data was recorded as a base line values. Patient received Fentanyl $1 \mu \mathrm{g} / \mathrm{kg}$ then dexmedtomidine loading dose $1 \mu \mathrm{g} / \mathrm{kg}$ over 10 min and followed by $0.5 \mu \mathrm{g} / \mathrm{kg} / \mathrm{hr}$ infusion till completion of surgery Dex (precedex 100 $\mu$ g $\mathrm{mL}-1$ Abbott laboratory) were diluted in preservative free normal saline.

Group $(\mathbf{K}+\mathbf{F})$ : After Pre -operative vital data was recorded as a base line values. Patient received Fentanyl $1 \mu \mathrm{g} / \mathrm{kg}$ and then ketamine $0.5 \mathrm{mg} / \mathrm{kg}$ slow intravenous bolus. Surgical procedure was started when Ramsay $^{(4)}$ sedation score 3 is achieved. If not achieved Propofol was given as incremental doses till RSS 3 is achieved.

\section{Statistical analysis:}

Recorded data were analyzed using the statistical package for social sciences, version 20.0 (SPSS Inc., Chicago, Illinois, USA). Quantitative data were expressed as mean \pm standard deviation (SD). Qualitative data were expressed as frequency and percentage.

The following tests were done: Independent-samples t-test of significance was used when comparing between two means.
Chi-square $\left(X^{2}\right)$ test of significance was used in order to compare proportions between two qualitative parameters. The confidence interval was set to $95 \%$ and the margin of error accepted was set to $5 \%$. So, the p-value was considered significant as the following: Probability (P-value). P-value $<0.05$ was considered significant. P-value $<0.001$ was considered as highly significant. P-value $>0.05$ was considered insignificant.

\section{RESULTS}

Table (1): Comparison between groups according to demographic data.

\begin{tabular}{|c|c|c|l|l|}
\hline $\begin{array}{c}\text { Demograph } \\
\text { ic Data }\end{array}$ & $\begin{array}{c}\text { Group KF } \\
(\mathrm{N}=25)\end{array}$ & $\begin{array}{c}\text { Group DF } \\
(\mathrm{N}=25)\end{array}$ & $\begin{array}{l}\mathrm{t} / \mathrm{x} 2 \\
\#\end{array}$ & $\begin{array}{l}\mathrm{p}- \\
\text { valu } \\
\mathrm{e}\end{array}$ \\
\hline Age (years) & & & & \\
\hline Range & $18-60$ & $18-59$ & $\begin{array}{l}0.76 \\
8\end{array}$ & $\begin{array}{l}0.24 \\
2\end{array}$ \\
\hline ASA & & & & \\
\hline I & $14(56 \%)$ & $15(60 \%)$ & $\begin{array}{l}2.64 \\
4 \#\end{array}$ & $\begin{array}{l}0.29 \\
1\end{array}$ \\
\hline
\end{tabular}

$\mathrm{x} 2$ : Chi-square test; $\mathrm{t}-$ Independent Sample ttest; $\mathrm{p}$-value $>0.05 \mathrm{NS}$

Table (1) shows no statistically significant difference between groups according to demographic data.

Table (2): Comparison between groups according to heart rate.

\begin{tabular}{|c|c|c|c|c|}
\hline $\begin{array}{l}\text { Heart } \\
\text { Rate }\end{array}$ & $\begin{array}{c}\text { Group KF } \\
(\mathrm{N}=25)\end{array}$ & $\begin{array}{c}\text { Group DF } \\
(\mathrm{N}=25)\end{array}$ & $\begin{array}{l}\text { t- } \\
\text { test }\end{array}$ & $\begin{array}{l}\text { p- } \\
\text { value }\end{array}$ \\
\hline $\begin{array}{l}\text { T0 } \\
\text { Range } \\
\text { Mean } \\
\pm \text { SD } \\
\end{array}$ & $\begin{array}{c}81-108 \\
99.54 \pm 6.51\end{array}$ & $\begin{array}{l}82-110 \\
97.92 \pm 7.10\end{array}$ & $\begin{array}{l}1.0 \\
42\end{array}$ & 0.156 \\
\hline $\begin{array}{l}\text { T1 } \\
\text { Range } \\
\text { Mean } \\
\pm \text { SD } \\
\end{array}$ & $\begin{array}{c}97-152 \\
117.04 \pm 11.3 \\
7 \\
\end{array}$ & $\begin{array}{l}71-118 \\
89.68 \pm 10.88\end{array}$ & $\begin{array}{l}9.1 \\
96\end{array}$ & $\begin{array}{l}<0.00 \\
1 * *\end{array}$ \\
\hline $\begin{array}{l}\text { T2 } \\
\quad \text { Range } \\
\text { Mean } \\
\pm \text { SD }\end{array}$ & $\begin{array}{c}100-135 \\
115.68 \pm 9.90\end{array}$ & $\begin{array}{l}73-103 \\
88.89 \pm 7.01\end{array}$ & $\begin{array}{l}8.4 \\
17\end{array}$ & $\begin{array}{l}<0.00 \\
1 * *\end{array}$ \\
\hline $\begin{array}{l}\text { T3 } \\
\quad \text { Range } \\
\text { Mean } \\
\pm \text { SD }\end{array}$ & $\begin{array}{c}98-128 \\
110.61 \pm 8.19\end{array}$ & $\begin{array}{l}74-119 \\
89.60 \pm 8.26\end{array}$ & $\begin{array}{l}8.5 \\
62\end{array}$ & $\begin{array}{l}<0.00 \\
1 * *\end{array}$ \\
\hline
\end{tabular}

t- Independent Sample t-test; p-value >0.05 NS; **p-value $<0.001 \mathrm{HS}$

Table (2) shows statistically significant difference between groups according to heart rate from $\mathrm{T} 1$ to $\mathrm{T} 3$. 
Table (3): Comparison between groups according to mean arterial blood pressure.

\begin{tabular}{|c|c|c|c|c|}
\hline $\begin{array}{l}\text { Mean Arterial } \\
\text { Blood Pressure }\end{array}$ & $\begin{array}{c}\begin{array}{c}\text { Group } \\
\text { KF } \\
(\mathbf{N}=25) \\
\end{array} \\
\end{array}$ & $\begin{array}{c}\text { Group } \\
\text { DF } \\
(\mathrm{N}=25) \\
\end{array}$ & $\begin{array}{c}\mathrm{t}- \\
\text { tes } \\
\mathrm{t}\end{array}$ & $\begin{array}{c}\text { p- } \\
\text { valu } \\
\text { e } \\
\end{array}$ \\
\hline $\begin{array}{l}\text { T0 } \\
\text { Range } \\
\text { Mean } \pm \text { SD }\end{array}$ & $\begin{array}{c}71-119 \\
92.22 \pm 14 . \\
56\end{array}$ & $\begin{array}{c}70-112 \\
91.04 \pm 12 \\
.08 \\
\end{array}$ & $\begin{array}{l}1.1 \\
77\end{array}$ & $\begin{array}{c}0.46 \\
7\end{array}$ \\
\hline $\begin{array}{l}\text { T1 } \\
\text { Range } \\
\text { Mean } \pm \text { SD }\end{array}$ & $\begin{array}{c}84-157 \\
115.64 \pm 2 \\
0.18 \\
\end{array}$ & $\begin{array}{c}56-127 \\
73.39 \pm 13 \\
.13 \\
\end{array}$ & $\begin{array}{c}10 . \\
39 \\
1 \\
\end{array}$ & $\begin{array}{l}<0.0 \\
01 * *\end{array}$ \\
\hline $\begin{array}{l}\text { T2 } \\
\text { Range } \\
\text { Mean } \pm \text { SD }\end{array}$ & $\begin{array}{c}76-167 \\
111.42 \pm 2 \\
1.69 \\
\end{array}$ & $\begin{array}{c}57-93 \\
73.73 \pm 8 \\
94 \\
\end{array}$ & $\begin{array}{l}9.5 \\
11\end{array}$ & $\begin{array}{l}<0.0 \\
01 * *\end{array}$ \\
\hline $\begin{array}{l}\text { T3 } \\
\text { Range } \\
\text { Mean } \pm \text { SD }\end{array}$ & $\begin{array}{c}74-139 \\
108.61 \pm 2 \\
0.76\end{array}$ & $\begin{array}{c}62-96 \\
76.24 \pm 6 \\
35\end{array}$ & $\begin{array}{l}9.6 \\
75\end{array}$ & $\begin{array}{l}<0.0 \\
01 * *\end{array}$ \\
\hline
\end{tabular}

t- Independent Sample t-test; p-value $>0.05$ NS; **p-value <0.001 HS

This table shows statistically significant difference between groups according to mean arterial blood pressure from T1 to T3.

Table (4): Comparison between groups according to sedation score.

\begin{tabular}{|c|c|c|c|c|}
\hline $\begin{array}{l}\text { Sedation } \\
\text { score }\end{array}$ & $\begin{array}{l}\text { Group KF } \\
(\mathbf{N}=25)\end{array}$ & $\begin{array}{l}\text { Group DF } \\
(\mathrm{N}=25)\end{array}$ & $\begin{array}{l}\text { t- } \\
\text { tes } \\
t\end{array}$ & $\begin{array}{l}\text { p- } \\
\text { valu } \\
\text { e }\end{array}$ \\
\hline \multicolumn{5}{|l|}{ T0 } \\
\hline Range & $2-5$ & $2-4$ & \multirow{2}{*}{$\begin{array}{l}0.4 \\
94\end{array}$} & \multirow{2}{*}{$\begin{array}{l}0.17 \\
9\end{array}$} \\
\hline $\begin{array}{l}\text { Mean } \pm \\
\text { SD }\end{array}$ & $3.53 \pm 0.79$ & $3.26 \pm 0.59$ & & \\
\hline \multicolumn{5}{|l|}{ T1 } \\
\hline Range & $3-5$ & $3-5$ & \multirow{2}{*}{$\begin{array}{l}5.0 \\
98\end{array}$} & \multirow{2}{*}{$\begin{array}{l}0.02 \\
1 *\end{array}$} \\
\hline $\begin{array}{l}\text { Mean } \pm \\
\text { SD }\end{array}$ & $3.88 \pm 0.70$ & $3.44 \pm 0.67$ & & \\
\hline \multicolumn{5}{|l|}{$\mathrm{T} 2$} \\
\hline Range & $3-6$ & $3-5$ & \multirow[b]{2}{*}{$\begin{array}{l}0.2 \\
07\end{array}$} & \multirow[b]{2}{*}{$\begin{array}{l}0.07 \\
5\end{array}$} \\
\hline $\begin{array}{l}\text { Mean } \pm \\
\text { SD } \\
\end{array}$ & $3.66 \pm 0.80$ & $3.27 \pm 0.61$ & & \\
\hline \multicolumn{5}{|l|}{ T3 } \\
\hline Range & $2-5$ & $2-4$ & \multirow{2}{*}{$\begin{array}{l}2.1 \\
53\end{array}$} & \multirow{2}{*}{$\begin{array}{l}0.78 \\
0\end{array}$} \\
\hline $\begin{array}{l}\text { Mean } \pm \\
\text { SD }\end{array}$ & $3.14 \pm 0.82$ & $3.04 \pm 0.53$ & & \\
\hline
\end{tabular}

t- Independent Sample t-test; *p-value $<0.05 \mathrm{~S}$

This table shows statistically significant difference between groups according to sedation score $\mathrm{T} 1$.
Table (5): Comparison between groups according to average dose of propofol supplementation.

\begin{tabular}{|c|c|c|c|c|}
\hline $\begin{array}{c}\text { Average Dose of } \\
\text { Propofol } \\
\begin{array}{c}\text { supplementation } \\
(\mathbf{m g})\end{array}\end{array}$ & $\begin{array}{c}\text { Group } \\
\text { KF } \\
(\mathbf{N}=\mathbf{2 5})\end{array}$ & $\begin{array}{c}\text { Group } \\
\mathbf{D F} \\
(\mathbf{N = 2 5})\end{array}$ & $\begin{array}{c}\mathbf{t}- \\
\text { tes } \\
\mathbf{t}\end{array}$ & $\begin{array}{c}\mathbf{p -} \\
\mathbf{v a l u} \\
\mathbf{e}\end{array}$ \\
\hline Mean \pm SD & $\begin{array}{c}2.16 \pm 0 . \\
58\end{array}$ & $\begin{array}{c}11.28 \pm \\
3.05\end{array}$ & $\begin{array}{c}7.9 \\
51\end{array}$ & $\begin{array}{c}<0.0 \\
01 * \\
*\end{array}$ \\
\hline
\end{tabular}

t- Independent Sample t-test; $* *$ p-value $<0.001$ HS

This table shows highly statistically significant difference between groups according to average dose of propofol supplementation.

Table (6): Comparison between groups according to recovery time.

\begin{tabular}{|c|c|c|c|c|}
\hline $\begin{array}{c}\text { Recover } \\
\text { y time }\end{array}$ & $\begin{array}{c}\text { Group KF } \\
(\mathbf{N}=25)\end{array}$ & $\begin{array}{c}\text { Group DF } \\
(\mathbf{N}=25)\end{array}$ & $\begin{array}{c}\mathbf{t}- \\
\text { tes } \\
\mathbf{t}\end{array}$ & $\begin{array}{c}\mathbf{p}- \\
\text { value }\end{array}$ \\
\hline $\begin{array}{c}\text { Mean } \pm S \\
\text { D }\end{array}$ & $20.39 \pm 4.11$ & $11.92 \pm 2.67$ & $\begin{array}{c}5.4 \\
22\end{array}$ & $\begin{array}{c}<0.0 \\
01 * *\end{array}$ \\
\hline
\end{tabular}

t- Independent Sample t-test; $* *$ p-value $<0.001$ HS

This table shows highly statistically significant difference between groups according to recovery time.

Table (7): Comparison between groups according to modified Alderet score.

\begin{tabular}{|c|c|c|c|c|}
\hline $\begin{array}{l}\text { Modified } \\
\text { alderet } \\
\text { score } \\
\end{array}$ & $\begin{array}{c}\text { Group } \\
\text { KF } \\
(\mathrm{N}=25)\end{array}$ & $\begin{array}{c}\text { Group } \\
\text { DF } \\
(\mathrm{N}=25)\end{array}$ & $\mathbf{x} 2$ & $\begin{array}{l}\text { p- } \\
\text { val } \\
\text { ue }\end{array}$ \\
\hline$<8$ score & $6(24 \%)$ & $18(72 \%)$ & \multirow{2}{*}{$\begin{array}{c}9 . \\
69 \\
6\end{array}$} & \multirow{2}{*}{$\begin{array}{c}0.0 \\
02 *\end{array}$} \\
\hline$>8$ score & $19(76 \%)$ & $7(28 \%)$ & & \\
\hline
\end{tabular}

x2: Chi-square test; ${ }^{*}$ p-value $<0.05 \mathrm{~S}$

\section{DISCUSSION}

Conscious sedation is technique of providing analgesia, sedation and anxiolysis while ensuring rapid recovery without side effects ${ }^{(5)}$.

Conscious sedation is administered with the dual goals of rapidly and safely establishing satisfactory procedural condition for the performance of therapeutic or diagnostic procedures while ensuring rapid, 
predictable recovery with minimal postoperative sequels.

Conscious sedation provides greater flexibility in scheduling operations so we can go with higher volume of patients. There is lack of dependence on the availability of hospital beds. There is also lower incidence of infection, respiratory complications and cardiovascular complication. It requires less preoperative testing and postoperative medication. Early recovery and early ambulation decreases morbidity and mortality rates. Conscious sedation also reduces overall procedural costs. Patients are able to observe the procedure and can communicate with surgeon during the procedure; therefore patients and surgeon satisfaction are high ${ }^{(5)}$.

Dexmedetomidine is a selective alpha2 agonist with analgesic and sedative properties. These properties of dexmedetomidine render it suitable for sedation and analgesia during the whole perioperative period. Its applications as a premedication, as an anesthetic adjunct for general and regional anesthesia and as a postoperative sedative and analgesic are similar to those of the benzodiazepines ${ }^{(6)}$.

Ketamine has a wide range of effects in humans including analgesia, anaesthesia, hallucinations, elevated blood pressure and bronchodilation. Ketamine induces a state referred to as "dissociative anaesthesia and is used as a recreational drug. In low doses typically used for conscious sedation it does not affect pharyngeal-laryngeal reflexes and, thus, allows a patent airway as well as spontaneous respirationto maintain intact ${ }^{(7)}$.

Cardiovascular and respiratory
stimulation are observed following administration, although transient respiratory depression may occur if administered too rapidly or in high doses. The unique dissociative action and partial agonism at opiate mu-receptors permits painful procedures to be performed in a consistent state of sedation and patient comfort. Ketamine is contraindicated in patients who have underlying conditions in which increased blood pressure would pose risk of complications. An increase in oropharyngeal secretions is often triggered and diligent patient monitoring for laryngospasms needs be employed ${ }^{(7)}$.
Opiates provide analgesia and sedation during painful procedures. Fentanyl is favored because of its prompt onset and short duration of action. Unlike morphine, fentanyl has minimal cardiovascular depressive effects and hypotension rarely occurs. Fentanyl binds with stereo specific receptors at many sites within the CNS and increases pain threshold, alters pain reception, and inhibits ascending pain pathways. In addition to analgesia, fentanyl suppresses the cough reflex and cause respiratory depression, drowsiness, and sedation. The half-life is 2-4 hours ${ }^{(8)}$.

In our study, continuous infusion of dexmedetomidine was used to maintain a steady state sedation level.

In our study, we found, about heart rate, there was significant difference between the two groups in $5^{\mathrm{TH}}$ min the mean heart rate was 117 with ketamine and fentanyl while mean heart rate was 89 with dexmedetomidine and fentanyl, in $10^{\mathrm{TH}}$ min the mean heart rate was 115 with ketamine and fentanyl while mean heart rate was 88 with dexmedetomidine and fentanyl and after stop of the infusion the mean heart rate was 110 with ketamine and fentanyl while mean heart rate was 89 with dexmedetomidine and fentanyl.

About blood pressure, there was a significant difference between the two groups, in $5^{\text {th }}$ minute the MBP was 111 with ketamine and fentanyl while MBP was 73 with dexmedetomidine and fentanyl, in $10^{\text {th }}$ minute the MBP was 115 with ketamine and fentanyl while MBP was 73 with dexmedetomidine and fentanyl and after stop of the infusion the MBP was 108 with ketamine and fentanyl while MBP was 76 with dexmedetomidine and fentanyl.

About the sedation score, there was a significant difference between the two groups in $5^{\mathrm{TH}}$ min was 3.88 with ketamine and fentanyl while was 3.44 with dexmedetomidine and fentanyl.

About recovery time, there was a significant difference between the two group, was 20 mins with ketamine and fentanyl while was $11 \mathrm{~min}$ with dexmedetomidine and fentanyl.

About Average Dose of Propofol Supplementation, there was highly statistically significant difference between groups, was 2 
mg with ketamine and fentanyl while was 11 $\mathrm{mg}$ with dexmedetomidine and fentanyl.

About modified aldert score 30 mins after end of the procedures and anesthesia infusion, there was a significant difference between the two groups,number of patients reaching MAS more than 8 was $19(76 \%)$ with ketamine and fentanyl while was 7 (28\%) with dexmedetomidine and fentanyl.

In study of Tarek et al. (9) who Compare of the efficacy of dexmedetomidine, ketamine, and a mixture of both for pediatric MRI sedation. there was a significant difference between the onset of satisfactory sedation in dexmedetomidine group (16.8) and Ketamine (4.6). this agree with our study but the difference between the groups was higher in this study.

In study of Tarek et al. ${ }^{(9)}$ also showed that patients in the dexmedetomidine group had significantly lower MBP compared to patients in the Ketamine group. In our study there was a significant decreased in MBP in dexmedetomidine and fentanyl group which agree with this study.

In study of Manoj ${ }^{(10)}$ who compare between Hemodynamic Stability and Recovery during Conscious Sedation with Dexmedetomidine or Propofol in Cardiac Catheterization Laboratory showed that In group D there was significant decrease in HR during procedure compared to group propofol $(\mathrm{p}<0.05)$. The mean HR was $21.63 \%$ lower than baseline with Dexmedetomidine and was $6.7 \%$ increased than baseline with propofol. These findings are consistent with our study results which showed a significant decrease in heart rate.

Also in the study of Manoj et al. showed that Recovery time, as assessed by modified Aldrete Score was significantly longer in propofol Group (13.93 \pm 3.11 minutes) compared to Dexmedetomidine group $(5.63 \pm 1.40$ minutes $){ }^{(5)}$. In our study, post-operative recovery time was longer in group KF than in group DF.

In study of Anchalee et al who Compare of Dexmedetomidine Versus Propofol on Hypotension During Colonoscopy Under Sedation To obtain and maintain a stable level of sedation or to treat discomfort, supplemental bolus doses of propofol $20 \mathrm{mg}$
IV bolus was given in both groups if the patient had moans, movements, and/or grimaces To obtain and maintain a stable level of sedation or to treat discomfort,. the mean dosage of propofol required during colonoscopy was significantly higher in Group Dexmedetomidine $(118 \mathrm{mg}$ than in propofol group $24.6 \mathrm{mg}(\mathrm{P}<0.001)$. our study agree with this result ${ }^{(11)}$.

In the study of Yağan et al. also showed that the time for reaching MAS 9 was $16 \mathrm{~min}$ in the ketamine and propofol group and $25 \mathrm{~min}$ in the dexmedetomidine group and the difference was statistically significant. This agree with our study ${ }^{(\mathbf{1 2})}$.

\section{CONCLUSION}

Dexmedetomidine exerts sedative and analgesic effects without respiratory depression, unlike most analgesic/sedative drugs, such as opioids, benzodiazepines, and propofol. Moreover, degree of satisfaction experienced by patients and obstetrician was better with dexmedetomidine. Therefore, dexmedetomidine in combination with fentanyl is useful to provide conscious sedation for dilatation and curettage (D\&C) procedures in adults and it may be a valuable alternative to ketamine.

\section{REFERENCES}

1. Jalowiecki P, Rudner R, Gonciarz $M$, Kawecki P, Petelenz M, Dziurdzik P (2005): Sole use of dexmedetomidine has limited utility for conscious sedation during outpatient colonoscopy. Anesthesiology, 103: 269-73.

2. Panzar O and Moitra V (2011): Pharmacology of sedative-analgesic agents: Dexmedetomidine, Remifentanil, Ketamine, volatile Anaesthetics, and the role of peripheral mu antagonists. Anaesthesiology Clinics, 29:587-605

3. Cheung CW, Ying CLA, Chiu WK et al. (2007): A comparison of dexmedetomidine and midazolam for sedation in third molar surgery. Anaesthesia, 62: 1132-8. 
4. Ramsay MA (2000): Measuring IeveI for sedation in the intensive care unit. JAMA., 284(4):44I 2.

5. Jalowiecki $P$, Rudner $R$, Gonciarz $M$ et al. (2005): Sole use of dexmedetomidine has limited utility for conscious sedation during outpatient colonoscopy. Anesthesiology, 103: 269-73.

6. Correa-Sales C, Rabin BC, Maze M (1992): A hypnotic response to dexmedetomidine, an alpha-2 agonist, is mediated in the locus coeruleus in rats. Anesthesiology, 76(6):948-52.

7. Sleigh J, Harvey M, Voss L et al. (2014): Ketamine - More mechanisms of action than just NMDA blockade. Trends in Anaesthesia and Critical Care, 4(2-3): 768.

8. Benyamin R, Trescot AM, Datta $\mathrm{S}$ et al. (2008): Opioid complications and side effects. Pain Physician, 11(2):105-20.

9. Tarek FT (2013): Comparison of the efficacy of dexmedetomidine, ketamine, and a mixture of both for pediatric MRI sedation. Egyptian Journal of Anaesthesia, 29(3): 241-246.

10. Manoj K, Geeta S, Kamlesh $\mathrm{K}$ et al. (2017): Comparative Evaluation of Efficacy, Hemodynamic Stability and Recovery during Conscious Sedation with Dexmedetomidine or Propofol in Cardiac Catheterization Laboratory. IOSR Journal of Dental and Medical Sciences, 4(5): 8387.

11. Techanivate A, Verawattaganon $T$, Saiyuenyong $\mathrm{C}$ et al. (2012): A comparison of dexmedetomidine versus propofol on hypotension during colonoscopy under sedation. J Anesth Clin Res., 3(11): 2-6.

12. Yağan Ö, Karakahya RH, Taş $\mathrm{N}$ et al. (2015): Comparison of dexmedetomidine versus ketamine-propofol combination for sedation in cataract surgery. Turkish Journal of Anaesthesiology and Reanimation, 43(2): 84. 